\title{
Nilai-Nilai Pendidikan Multikultural dalam Perspektif Pemikiran Nurcholish Madjid
}

\author{
Nurjannah Nasution'1, Erawadi², Anhar ${ }^{3}$ \\ ${ }^{1}$ MAS Al-Ahliyah Aek Badak Tapanuli Selatan, \\ 2, 3IAIN Padangsidimpuan \\ 1jannahnst93@gmail.com, 2era08_nad@yahoo.co.id, 3anharnst@gmail.com
}

\begin{abstract}
This study aims to reveal the meaning and values of multicultural education in the perspective of Nurcholish Madjid's thinking by using the research method of character studies. The results of this study can be concluded that Nurcholish Madjid that in referring to the multicultural term Nurcholish Madjid uses the term plurality more. Plurality is a plural or plural society which is the design and sunnatulah Allah Almighty for mankind because there is no single and equal society in all aspects. The multicultural education values found, namely the value of democracy (must be absolutivism / free to express opinions and accept criticism), the value of justice (must be fair and be a referee / mediator in upholding something), the value of equality (all human beings are the same that distinguishes only the level devotion), human values (humans are not justified to denigrate one another) and tolerance values (mutual respect and respect for other religions and give freedom of worship).
\end{abstract}

Keywords: Education; Multicultural; Nurcholish Madjid.

\begin{abstract}
Abstrak
Penelitian ini bertujuan untuk mengungkapkan makna dan nilai-nilai pendidikan multikultural dalam perspektif pemikiran Nurcholish Madjid dengan menggunakan metode penelitian studi tokoh. Hasil penelitian menunjukkan bahwa Nurcholish Madjid dalam menyebut istilah multikultural lebih banyak menggunakan istilah pluralitas. Pluralitas adalah suatu masyarakat majemuk atau plural yang merupakan design dan sunnatulah Allah swt untuk umat manusia karena tidak ada masyarakat yang tunggal dan sama dalam semua segi. Adapun nilai-nilai pendidikan multikultural yang didapati, yaitu nilai demokrasi (harus absolutivisme/ bebas mengutarakan pendapat dan menerima kritikan), nilai keadilan (harus bersikap adil dan menjadi wasit/penengah dalam menegakkan
\end{abstract}


sesuatu), nilai kesetaraan (semua manusia sama yang membedakannya hanya tingkat ketaqwaan), nilai kemanusiaan (manusia tidak dibenarkan untuk merendahkan satu sama lain) dan nilai toleransi (saling menghormati dan menghargai agama lain serta memberi kebebasan beribadah).

Kata Kunci: Pendidikan; Multikultural; Nurcholish Madjid.

\section{PENDAHULUAN}

Dalam Islam, multikultural adalah sebuah sunatullah atau desain Tuhan yang tidak dapat dihilangkan dari panggung kehidupan dan tidak dapat juga disangkal oleh siapapun. Sebagaimana pepatah Arab menyebutnya sebagai keniscayaan hidup (min lawa zim al-hayah). ${ }^{1}$ Dalam Al-quran Allah swt berfirman pada QS. Al-Hujurat ayat 13, yaitu sebagai berikut:

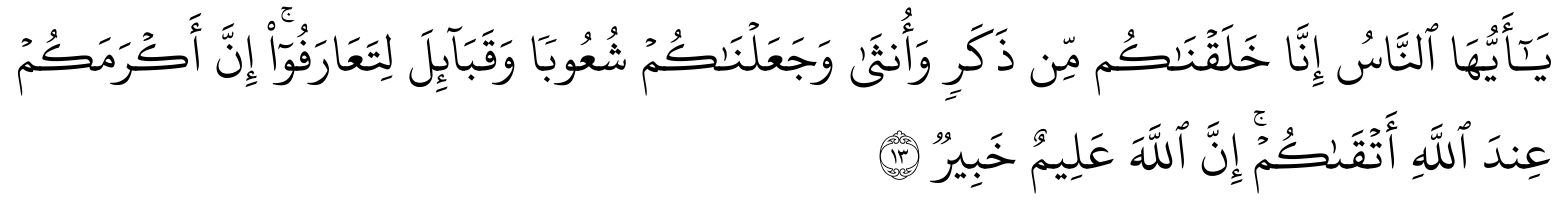

Artinya: "Hai manusia, sesungguhnya Kami menciptakan kamu dari seorang lakilaki dan seorang perempuan serta menjadikan kamu berbangsa-bangsa dan bersuku-suku supaya kamu saling kenal-mengenal. Sesungguhnya orang yang paling mulia di antara kamu di sisi Allah swt adalah orang yang paling takwa di antara kamu. Sesungguhnya Allah Maha mengetahui lagi Maha Mengenal". ${ }^{2}$

Konsep multikultural juga sudah ada sejak masa Rasulullah saw yang terdapat pada Piagam Madinah. Konteks Piagam Madinah menyiratkan yang pertama bahwa semua manusia merupakan ummatan wahidah. Artinya, walaupun memiliki perbedaan tetap umat yang satu. Kedua, adanya prinsip-prinsip kesetaraan dalam hubungan interaksi antar muslim dengan non muslim yaitu

1Samrin, "Konsep Pendidikan Multikultural", Jurnal al-Ta'dib, Volume 7 Nomor 2 Tahun 2014, hlm. 121.

${ }^{2}$ Kementerian Agama Islam RI, Al-qur'an Al-karim dan Terjemahannya (Semarang: Halim, 2014), hlm. 517. 


\section{Nurjannah Nasution}

saling berinteraksi dengan baik, menghormati kebebasan beragama, membela yang tertindas dan saling bergenggaman tangan dalam mempertahankan Negara. ${ }^{3}$

Indonesia adalah negara yang sangat kaya akan kultur, suku, bahasa dan agama. Indonesia terdiri dari beberapa pulau dan setiap pulau terdiri dari beberapa provinsi. Setiap provinsi terdiri dari beberapa wilayah dan setiap wilayah dihuni oleh manusia, yang dimana manusia tersebut membentuk suatu kelompok masyarakat yang memiliki budaya sendiri. Berdasarkan keragaman tersebut, maka terbentuklah sebuah semboyan, yaitu "Bhinneka Tunggal Ika" artinya walaupun berbeda-beda tetap satu jua.

Keragaman yang dimiliki bangsa Indonesia bagaikan pisau bermata dua, yang artinya bahwa pada sisi yang satu menjadikan Indonesia kaya. Sedangkan di sisi lain, dapat menimbulkan konflik atau kerusuhan atas dasar background SARA (suku, adat, ras, agama). Hal itu dibuktikan dengan banyaknya konflik yang terjadi, seperti konflik berbau SARA di Palu dan Ambon, pengeboman di Bali, konflik etnis di Sampit dan Sambas. Selanjutnya, konflik mengenai penyerangan jama'ah Ahmadiyah di Cikeusik, Pandeglang dan Banten. Kemudian pembakaran masjid Ahmadiyah di berbagai wilayah dan perusakan sejumlah gereja di Temanggung, Jawa Tengah. ${ }^{4}$

Salah satu sarana yang dapat ditempuh dalam menjaga Kebhinekaan Tunggal Ikaan Indonesia yaitu lewat pendidikan. Sebagaimana ungkapkan Nelson Mandele yang dikutip Wardatul Auliya, mengatakan bahwa pendidikan adalah senjata paling mematikan di dunia, sebab dengan pendidikan manusia dapat merubah dunia. Pendidikan adalah sarana yang paling efektif dalam merealisasikan kesadaran akan pentingnya menjaga kedamaian, kerukunan dan keharmonisan terhadap keragaman yang ada. Untuk meminimalisir terjadinya

3Usman, "Civil Society dan Multikulturalisme dalam Pendidikan Islam", Jurnal Tadrîs, Volume 11 Nomor 1 Tahun 2016, hlm. 5.

4Samrin, "Konsep Pendidikan", hlm. 131. 
sebuah konflik, maka diperlukan upaya pendidikan yang berwawasan multikultural, yaitu pendidikan multikultural. ${ }^{5}$

Pendidikan multikultural adalah suatu proses penanaman sikap menghargai serta menghormati keragaman atau kemajemukan yang ada dalam kehidupan masyarakat. Dengan adanya pendidikan, bangsa Indonesia dapat mengurangi atau bahkan menyelesaikan sebuah konflik bernuansa keragaman suku, ras, bahasa dan agama. Melalui pendidikan, maka masyarakat Indonesia dapat memunculkan kesadaran nilai-nilai hidup dalam perbedaan budaya. ${ }^{6}$

Pendidikan multikultural sangat penting diorientasikan agar mampu menghormati dan menghargai keragaman menjadi kesatuan. Nilai-nilai pendidikan multikultural direalisasikan dengan upaya membiasakan sikap mutual understanding (saling pengertian), mutual respect (saling menghargai) dan mutual trust (saling percaya) terhadap keragaman suku, ras, bahasa serta agama yang merupakan prinsip pendidikan multikultural. ${ }^{7}$

Untuk meorientasikannya, maka perlu adanya pemikiran-pemikiran dari cendikiawan Muslim yang dijadikan sebagai orientasi dalam menyikapi keberagaman atau multikultural. Di Indonesia, banyak lahir cendikiawan Muslim atau tokoh pemikir pembaharuan Islam yang banyak menyinggung tentang keragaman atau kemajemukan yang sering disebut pluralitas. Sekarang, istilah tersebut identik dengan istilah multikultural. Adapun tokohnya di antaranya seperti Nurcholish Madjid.

Menurut Nurcholish Madjid, pluralitas adalah kemajemukan masyarakat yang merupakan suatu design atau dektrit Allah swt untuk umat manusia yang di dalamnya tidak ada masyarakat yang monolitik, tunggal, sama dan sebangun dalam segala hal dari berbagai suku ataupun agama. ${ }^{8}$

${ }^{5}$ Abdul Aziz, "Desain Pendidikan Multikultural dalam Pendidikan Islam", Jurnal Penelitian Realita, Volume 15 Nomor 1 Tahun 2017, hlm. 2-3.

6Zakiyuddin Baidhawy, Pendidikan Agama Berwawasan Multikultural (Jakarta: PT Erlangga, 2005), hlm. 8.

7Yaya Suryana dan A. Rusdiana, Pendidikan Multikultural Suatu Upaya Penguatan Jati Diri Bangsa (Bandung: Pustaka Setia, 2015), hlm. 200.

8Nurcholish Madjid, Islam Agama Kemanusiaan (Jakarta: Paramadina, 1995), hlm. 1996. 
Nurcholish Madjid adalah cendikiawan Muslim dan tokoh pemikir yang mengkaji serius tentang multikultural. Nurcholish Madjid memberikan perhatian khusus terhadap multikultural dan mengkajinya dengan serius melalui karyakaryanya atau diskusi-diskusi ilmiah. Pada tahun 70 -an, ia menaruh perhatian pada tiga tema, yaitu keislaman, kemodernan dan keindonesiaan. Gagasan tersebut menjadi pangkal tolak konsep inklusif yang berpijak pada semangat multikultural. Nurcholish Madjid menegaskan bahwa dalam bernegara, pancasila harus dijadikan sebagai pemersatu dan kalimatun sawa yang bertujuan mengajak semua orang untuk patuh dengan ajaran Tuhan serta menghargai dan menghormati keberagaman. Dengan adanya Pancasila, maka sangatlah diuntungkan dalam semangat multikulturalisme untuk mencegah terjadinya konflik. Pancasila adalah ideologi bangsa Indonesia dan tiap-tiap nilai dari kelima sila atau sila pertama sampai sila ke lima melahirkan suatu pandangan dalam berkehidupan. 9

Nurcholish Madjid atau yang sering dipanggil dengan Cak Nur, lahir tanggal 17 Maret 1939 di Jombang, Jawa Timur. Pada tanggal 29 Agustus 2005, Nurcholish Madjid menghembuskan nafas terakhir di Rumah Sakit Pondok Indah Jakarta. Nurcholish Madjid banyak mengeluarkan ide-ide atau pemikiranpemikiran yang begitu cemerlang. Nurcholish Madjid menuangkan pemikirannya ke dalam buku dan dipublikasikan sehingga menjadi sebuah karya yang monumental. Di antara buku-buku tersebut banyak pemikiran-pemikirannya yang mengarah ke nilai-nilai pendidikan multikultural. Selain dari buku-buku yang diterbitkan, Nurcholish Madjid juga banyak menulis makalah dan artikel. Karyakarya yang dihasilkan tersebut menjadi sebuah rujukan dan sampai sekarang tulisan-tulisannya masih relevan untuk dikaji.

\section{METODE PENELITIAN}

Jenis penelitian yang digunakan dalam penelitian ini adalah penelitian kepustakaan (library research). Penelitian kepustakaan (library research) yaitu

9Muammar Munir, "Nurcholish Madjid dan Harun Nasution serta Pengaruh Pemikiran Filsafatnya", Jurnal Petita, Volume 2 Nomor 2 Tahun 2017, hlm. 218. 
suatu rangkaian penelitian yang di mana objek penelitiannya digali lewat berbagai macam informasi kepustakaan seperti buku, jurnal ilmiah, majalah, ensiklopedi, koran dan dokumen. ${ }^{10}$

Penelitian ini menggunakan metode penelitian studi tokoh. Penelitian studi tokoh adalah pengkajian secara sistematis terhadap pemikiran atau gagasan seseorang pemikir Muslim, yaitu Nurcholish Madjid. Kemudian teknik analisis data yang digunakan yaitu Content Analysis (analisis isi) dengan menggunakan metode hermeneutika. Content Analysis adalah suatu analisis teks yang bertujuan untuk mengumpulkan muatan dari sebuah teks dan menganalisis muatan teks tersebut. ${ }^{11}$

Adapun sumber data primernya adalah sebuah karya-karya monumental yang ditulis sendiri oleh tokoh yang dikaji, yaitu berupa pemikiran-pemikiran Nurcholish Madjid yang tertuang dalam bentuk tulisan. Sedangkan sumber data sekundernya adalah data yang didapatkan dari tangan kedua yang informasinya tidak langsung didapat dari objek penelitian, yaitu berupa buku-buku baik edisi cetak maupun internet. Di dalam literatur tersebut pembahasannya berkaitan dengan topik yang dikaji yaitu mengenai nilai-nilai pendidikan multikultural.

Adapun langkah-langkah yang digunakan dalam meneliti, yaitu pertamatama, membaca seluruh isi pemikiran Nurcholish Madjid dari awal sampai akhir yang tertuang di dalam buku yang merupakan hasil karyanya. Kemudian, menelaah isi buku dengan cara menandai pernyataan-pernyataan yang terkait dengan nilai-nilai pendidikan multikultural. Selanjutnya, mengelompokkan atau mengklasifikasikan jenis pernyataan yang sesuai dengan nilai-nilai pendidikan multikultural, yaitu nilai demokrasi, nilai keadilan, nilai kesetaraan, nilai kemanusiaan dan nilai toleransi. Kemudian mengumpulkan bahan ataupun sumber-sumber berupa buku-buku, artikel maupun jurnal yang berkaitan dengan kajian multikultural. Langkah terakhir yaitu mengambil kesimpulan dari

${ }^{10}$ Nana Syaodih, Metode Penelitian Pendidikan (Bandung: PT. Remaja Rosdakarya, 2009), hlm. 52.

${ }^{11}$ Syahrin Harahap, Metodologi Studi Tokoh Pemikiran Islam (Jakarta: Prenada, 2011), hlm. 6. 


\section{Nurjannah Nasution}

keseluruhan hasil interprestasi mengenai nilai-nilai pendidikan multikultural dalam perspektif pemikiran Nurcholish Madjid.

\section{HASIL DAN PEMBAHASAN}

\section{Makna Multikultural dalam Perspektif Pemikiran Nurcholish Madjid}

Istilah multikultural merujuk pada istilah multikulturalisme, dalam konteks negara Kanada, istilah ini pertama kali dipopulerkan dan digunakan atau dipergunakan sebagai sinonim dari pluralisme. Istilah masyarakat multikultural pertama kali digunakan di Kanada sekitar tahun 1950-an.12

Secara Bahasa, istilah multikultural mengandung dua pengertian yaitu "multi" dan "kultural". Pengertian multi adalah plural, sedangkan kultural adalah kultur atau budaya. Dengan itu, pengistilahan multi mengandung arti sebagai berjenis-jenis. Yang di mana dalam hal ini tidak hanya untuk pengakuan saja terhadap yang berjenis, akan tetapi di samping itu harus ada juga pengakuan yang mempunyai implikasi luas dan kompleks yang berhubungan dengan ideologi, ekonomi dan politik. ${ }^{13}$

Sedangkan multikulturalisme adalah suatu paham atau keyakinan untuk mengakui, menghargai dan menghormati perbedaan dalam kesetaraan baik secara individual maupun sosial. Suatu gerakan yang muncul dari konsep multikultural adalah gerakan multikulturalisme. Dalam realitanya, multikulturalisme sudah digunakan oleh para pendiri bangsa Indonesia sebagai acuan dalam merangkul semua keberagaman yang disemboyankan dengan "Bhinneka Tunggal Ika", yaitu biapun berbeda-beda tetap satu jua. Artinya, setiap masyarakat sampai kapanpun tetap satu, satu bangsa, satu tanah air dan satu bahasa, yaitu Indonesia ${ }^{14}$

${ }^{12 K a s i n y o ~ H a r t o, ~ M o d e l ~ P e n g e m b a n g a n ~ P e n d i d i k a n ~ A g a m a ~ I s l a m ~ B e r b a s i s ~ M u l t i k u l t u r a l ~}$ (Jakarta: Rajawali Pers, 2014), hlm. 15.

${ }^{13}$ Sulalah, Pendidikan Multikultural Didaktika Nilai-Nilai Universalitas Kebangsaan (Malang: UIN Maliki Press, 2011), hlm. 42.

${ }^{14}$ Muhammad Tholchah Hasan, Pendidikan Multikultural Sebagai Opsi Penanggulang Radikalisme (Malang: Universitas Malang, 2011), hlm. 134. 
Begitu juga dalam Islam, multikultural merupakan sunnatullah yang tidak dapat dipungkiri oleh siapapun. Keragaman tidak perlu disangkal dan hendaknya dipakai sebagai pangkal tolak untuk berlomba-lomba menuju kebaikan (fastabiqu al-khairat). Perbedaan itu mulai dari jenis kelamin, suku dan bangsa yang beranekaragam dan dapat melahirkan sikap saling mengenal (ta'aruf). Dari saling mengenal lahirlah mutual understanding (sikap saling memahami), lalu dari saling memahami lahir mutual respect (sikap saling menghargai). Selanjutnya, dari saling menghargai lahir mutual trust (sikap saling percaya). ${ }^{15}$

Sebagai pemikir dan teolog, pemikiran Nurcholish Madjid sangat berpengaruh di dalam masyarakat. Gerakan Nurcholish Madjid adalah gerakan kultural yang memiliki ciri inklusif, yaitu merangkul semua kalangan tanpa membedakan suku, ras dan bahkan agama. Sebagai penganjur paham pluralisme dan inklusifisme yang otentik, Nurcholish Madjid sebagai lokomotif gerakan pembaharuan pemikiran Islam. Pengaruh gagasan-gagasan tersebut sangat besar terhadap perilaku politik umat Islam Indonesia.

Pemikiran Nurcholish Madjid sangat kental dengan gagasan pluralitas. Nurcholish Madjid mengatakan bahwa pluralitas meningkat menjadi pluralisme, yaitu suatu sistem nilai yang memandang secara positif terhadap segala kemajemukan.

"Kemajemukan atau pluralitas umat manusia adalah kenyataan yang telah menjadi kehendak Tuhan. Jika dalam Kitab Suci disebutkan bahwa manusia diciptakan berbangsa-bangsa dan bersuku-suku agar mereka saling mengenal dan menghargai, maka pluralitas itu meningkat menjadi pluralisme, yaitu suatu sistem nilai yang memandang secara positif optimis terhadap kemajemukan itu sendiri, dengan menerimanya sebagai kenyataan dan berbuat sebaik mungkin berdasarkan kemajemukan itu. Dalam Kitab Suci juga disebutkan bahwa perbedaan antara manusia dalam Bahasa dan warna kulit harus diterima sebagai kenyataan yang positif, yang merupakan salah satu tanda-tanda kebesaran Allah (QS., 30:22). Juga terdapat penegasan tentang kemajemukan dalam pandangan

15Sulalah, Pendididikan Multikultural..., hIm. 59. 


\section{Nurjannah Nasution}

dan cara hidup antara manusia yang tidak perlu digusarkan dan hendaknya dipakai tolak berlomba-lomba menuju berbagai kebaikan (QS., 5:48)". ${ }^{16}$

Dalam kehidupan bermasyarakat, di dalamnya tidak ada terdapat masyarakat yang monolitik, tunggal dan sama dalam segala hal. Akan tetapi, di dalam masyarakat terdapat suatu masyarakat yang majemuk yang terdiri dari berbagai suku, bahasa dan agama. Dari hal tersebut, maka sikap penuh pengertian harus tertanam pada setiap individu. Menurut Nurcholish Madjid, multikultural merupakan design atau dekrit Allah swt untuk umat manusia. ${ }^{17}$

Berdasarkan pernyataan Nurcholish Madjid di atas, bahwa "pluralitas itu meningkat menjadi pluralism" merupakan suatu konsep multikultural. Dalam hal ini, pluralitas merupakan nilai-nilai yang kemudian meningkat menjadi pluralisme yang merupakan sitem nilai yang dipandang secara positif. Untuk itu, istilah yang dilontarkan Nurcholish Madjid sama dengan istilah multikultural.

\section{Nilai-nilai Pendidikan Multikultural dalam Perspektif Pemikiran Nurcholish Madjid}

\section{Demokrasi}

Dalam khazanah Islam, dikenal istilah syura' yang secara prinsip sejalan dengan demokrasi. Kata syura 'merupakan bentuk mashdar dari syaawara, yang artinya meminta pendapat orang lain yang bisa dan layak diminta pendapat. Musyawarah hakikatnya adalah interaksi yang baik antar sesama individu untuk saling memberi hak dalam menyatakan pendapat dan saling mengakui adanya kewajiban mendengar. Tujuan dari sistem musyawarah adalah bertujuan untuk mencapai suatu mufakat bersama dan hal ini telah ada sejak Nabi Muhammad saw menjadi pemimpin di Madinah. ${ }^{18}$

Pemikiran Nurcholish Madjid tentang demokrasi bertitik tumpu pada pemahamannya tentang nilai-nilai musyawarah. Dalam hal ini, Nurcholish Madjid

${ }^{16}$ Nurcholish Madjid, Islam Doktrin dan Peradaban; Sebuah Telaah Kritis Tentang Masalah Keimanan, Kemanusiaan dan Kemodernan (Jakarta: Paramadina, 2005), hlm. xxv.

${ }^{17}$ Nurcholish Madjid, Islam Agama..., hlm. 196.

18Haryanto Al-Fandi, Desain Pembelajaran Yang Demokratis dan Humanis (Jogjakarta: ArRuzz media, 2011), hlm. 66-67. 
menggambarkan musyawarah sebagi kenyataan dari masyarakat majemuk, yaitu sebagai berikut:

"Musyawarah pada hakikatnya tidak lain adalah interaksi positif sebagai individu dalam masyarakat yang saling memberi hak untuk menyatakan pendapat dan saling mengakui adanya kewajiban mendengar pendapat itu. Dalam Bahasa lain, musyawarah adalah hubungan intekratif untuk saling mengikatkan tentang kebenaran dan kebaikan serta ketabahan dalam mencari penyelesaian masalah bersama, dalam suasana persamaan hak dan kewajiban antar warga masyarakat". ${ }^{19}$

Pernyataan Nurcholish Madjid di atas, bahwa dalam musyawarah, setiap komponen harus tulus dan serius dalam mendengarkan dan menghargai pendapat dari yang lain serta memberikan pendapat harus bersikap baik tanpa emosi. Jika ada perbedaan antar satu sama lain, maka setiap komponen harus bersikap hormat dan respek antar sesama. Dari pernyataan tersebut, musyawarah merupakan bagian dari demoktrasi.

\section{Keadilan}

Keadilan dalam Kamus Besar Bahasa Indonesia, berasal dari kata adil, yaitu tidak memihak, tidak berat sebelah, tidak semena-mena dan mendapat perlakuan (jaminan) yang sama. Sedangkan keadilan adalah sifat atau perbuatan, perlakuan dan sebagainya. ${ }^{20}$

Kata adil dalam Al-quran disebutkan sebanyak 28 kali dan bersinonim dengan al-qisti (keseimbangan) yang disebutkan sebanyak 25 kali. Dalam konsepsi Islam, berlaku adil adalah keharusan dalam menerapkan keputusan hukum di antara manusia. Al-quran menegaskan bahwa keadilan dijalankan dengan teguh terhadap semua manusia tanpa kecuali. Berbuat adil merupakan nilai absolut dan harus ditegakkan dalam segala situasi apapun, bahkan dalam situasi yang genting sekalipun. ${ }^{21}$

19Nurcholish Madjid, Cita-Cita Politik Islam Era Reformasi (Jakarta: Paramadina, 1999), hlm. 178.

20Tim Penyusun Kamus Pusat Bahasa, Kamus Besar..., hlm. 8.

21Haryanto Al-Fandi, Desain Pembelajaran..., hlm. 61. 
Bersikap adil bukan hanya dilaksanakan untuk keluarga dan sahabat karib dan kerabat, melainkan juga untuk musuh bahkan lawan sekalipun. Sehingga harus dilakukan tanpa pandang status sosialnya, seperti orang kaya maupun miskin, orang berpangkat maupun rakyat biasa, orang pintar maupun orang bodoh, yang kuat maupun yang lemah, orang dewasa maupun anak-anak, baik yang seagama maupun non-seagama bahkan terhadap diri sendiri. 22

Menurut Nurcholish Madjid, bahwa di dalam Kitab Suci Al-quran banyak menyinggung masalah keadilan dengan berbagai konteks. Selain menggunakan perkataan adl juga menggunakan perkataan wasth, qisth dan mizan. Kata adl artinya, wawasan seimbang dalam menyikapi, memandang dan menilai sesuatu. Sedangkan kata wasth disebut tengah, yaitu kaum beriman dirancang oleh Allah swt untuk menjadi golongan tengah (ummat wasth). Sedangkan dalam Bahasa Indonesia, wasth disebut dengan wasit, yaitu penengah. ${ }^{23}$

Pernyataan Nurcholish Madjid, yaitu:

"Keadilan dalam maknanya adalah sebagai sikap yang fair dan berimbang kepada sesama manusia. Dalam hal ini, adanya pengakuan yang tulus, bahwa manusia dan pengelompokannya selalu beraneka ragam, plural ataupun majemuk. Dengan kata lain, pandangan terhadap kemanusiaan yang adil dapat melahirkan kemantapan bagi prinsip pluralisme sosial, yang dijiwai oleh sikap saling menghargai dalam hubungan antar pribadi dan kelompok masyarakat. Persatuan tidak mungkin terwujud tanpa adanya sikap saling menghargai. Selanjutnya, persatuan yang akan membawa kemajuan adalah persatuan yang dinamis, yaitu persatuan dalam kemajemukan yang terkandung dalam semboyan Binneka Tunggal Ika. Prinsip kemanusiaan adalah satu, namun terdapat kebhinekaan dalam kesatuaan tersebut". ${ }^{24}$

22Syahrin Harahap dan Hasan Bakti Nasution, Ensiklopedi Akidah Islam (Jakarta: Kencana, 2009), hlm. 19.

23Nurcholish Madjid, Masyarakat Religius (Jakarta: Paramadina, 1997), hlm. 134.

${ }^{24}$ Nurcholish Madjid, Islam Kemodernan..., hlm. 58. 
Secara positif, keragaman atau kemajemukan tersebut diapresiasi dan dibingkai dalam motto, yaitu "Bhinneka Tunggal Ika". Artinya, biarpun berbeda dari segi apaupun tetap juga satu. Motto tersebut merupakan dasar kuat bagi paham kemajemukan masyarakat. Akan tetapi keanekaragaman juga dapat menjadi sumber kerawanan.

\section{Kemanusiaan}

Kemanusiaan adalah sikap menjunjung tinggi nilai-nilai kemanusiaan, yaitu dengan melakukan kegiatan kemanusiaan dan menebarkan kasih sayang antar sesama manusia. ${ }^{25}$ Manusia adalah makhluk ciptaan Allah swt yang dimuliakan dan sebagai khalifah-Nya. Kemudian manusia diberikan potensi agar manusia dapat melaksanakan atau menjalankan fungsinya sebagai hamba Allah swt. 26

Dalam pemikiran Nurcholish Madjid bahwa kemanusiaan harus dijaga dengan baik terhadap semua golongan-golongan yang ada. Sebagaimana yang pernah diterapkan Nabi Muhammad saw di Madinah yang mempersaudarakan antara kelompok yang datang dari Mekah (Muhajirin) dengan kelompok pribumi Madinah (Anshar). Sikap saling mengasihi dan menyayangi mampu membangun kehidupan yang aman, damai, harmonis dan erat serta adanya perasaan bagaikan satu tubuh.

"Persaudaraan diperlukan, karena tidak mungkin menghilangkan perbedaan antara manusia, termasuk kalangan kaum beriman sendiri. Melalui semangat persaudaraan diusahakan mengubah perbedaan menjadi pangkal sikap hidup yang positif, seperti berlomba-lomba menuju kepada berbagai kebaikan (al-khairat), dengan sikap saling menghormati sesama anggota masyarakat dan menghargai pendirian serta pandangan hidup masing-masing. Jika al-qur’an memberi petunjuk bahwa yang utama dan pertama harus kita lakukan adalah, "jangan ada suatu golongan

${ }^{25}$ Kasinya Karto, Model Pengembangan..., hlm. 63.

${ }^{26}$ Haidar Putra Daulay, Pemberdayaan Pendidikan Islam di Indonesia (Jakarta: Rineka Cipta, 2009), hlm. 121. 


\section{Nurjannah Nasution}

merendahkan golongan lain, sebab boleh jadi mereka yang direndahkan itu lebih baik daripada mereka yang merendahkan". ${ }^{27}$

Adanya semangat persaudaraan menjadikan sebuah perbedaan ataupun keragaman sebagai pangkal sikap hidup untuk saling berlomba-lomba melakukan kebaikan (al-khayrât). Hal tersebut dapat tercapai jika tumbuh sikap saling menghargai dan menghormati keragaman yang ada. Jika ada yang membunuh seseorang tanpa ada alasan yang sah maka ia bagaikan merugikan seluruh umat manusia. Sebaliknya, jika ada yang berbuat baik dalam hal menolong seseorang, maka ia bagaikan berbuat baik kepada seluruh manusia. Setiap pribadi manusia adalah berharga, yaitu seharga kemanusiaan sejagat. 28

Dengan hal tersebut, maka sesama umat Muslim adalah bersaudara, yaitu persaudaraan yang di dalamnya menebarkan cinta kasih atau kasih sayang antara sesama sehingga perbedaan yang ada tidak menjadi suatu perdebatan yang menimbulkan konflik.

\section{Kesetaraan}

Kesetaraan berasal dari kata tara yang berarti sama, banding dan imbangan. Kesetaraan artinya seimbang dan sejajar. Dalam bahasa Arab, kesetaraan sama dengan al-musawah yang artinya rata dan sama. ${ }^{29}$

Setiap manusia mengakui kesetaraan antara manusia satu dengan yang lain. Pengakuan kesetaraan derajat, kesetaraan hak dan kesetaraan kewajiban sesama manusia. Dengan begitu, manusia dilindungi hak-hak dan memperoleh haknya setelah melakukan kewajiban-kewajibannya Kesetaraan penting dalam kondisi masyarakat yang beragam. Kesetaraan, Kebersamaan adalah kesatuan perasaan dan sikap dalam hubungan manusia satu dengan yang lain, meskipun mempunyai perbedaan suku, budaya, agama, ras, etnik dan strata sosial. ${ }^{30}$

27Nurcholish Madjid, Masyarakat Religius..., hlm. 41.

${ }^{28}$ Nurcholish Madjid, Islam Agama..., hlm. 196.

29Tim Penyusun Kamus Pusat Bahasa, Kamus Bahasa..., hlm. 1631.

${ }^{30}$ Abdullah Aly, Pendidikan Islam Multikultural di Pesantren (Yogyakarta: Pustaka Pelajar, 2011), hlm. 116. 
Sebagaimana pernyataan Nurcholish Madjid bahwa sesama manusia tidak diperkenankan untuk membeda-bedakan satu dari yang lain dalam hal harkat dan martabat. Sebab, menurut asal-muasalnya manusia adalah satu karena diciptakan dari jiwa yang satu.

"Umat manusia akan tetap berbeda-beda sepanjang masa. Semata-mata tidak mungkin membayangkan bahwa umat manusia adalah satu dan sama dalam segala hal sepanjang masa. Konsep kesatuan umat manusia adalah suatu hal yang berkenaan dengan kesatuan harkat dan martabat manusia itu, antara lain karena menurut asal-muasalnya manusia adalah satu karena diciptakan dari jiwa yang satu. Karena itu sesama manusia tidak diperkenankan untuk membeda-bedakan satu dari yang lain dalam hal harkat dan martabat. Hanya dalam pandangan Allah swt manusia berbedabeda dari satu pribadi ke pribadi lainnya dalam hal kemuliaan, berdasarkan tingkat ketaqwaan kepada Allah swt. Sedangkan sesama manusia sendiri, pandangan yang benar adalah bahwa semua pribadi adalah sama dalam harkat dan martabat dengan imbasannya dalam kesamaan hak dan kewajiban asasi”. 31

Persamaan manusia yang mendasari nilai-nilai kemanusiaan dicontohkan oleh Nabi Muhammad saw. Beliau sangat dekat dengan kaum miskin juga kepada anak yatim dan beliau berusaha membebaskan budak serta mengurangi perbudakan. Maka dari itu beliau membebaskan budak bernama Zaid ibn Haristh yang kemudian Rasulullh saw angkat sebagai anak. ${ }^{32}$

\section{Toleransi}

Dalam Kamus Besar Bahasa Indonesia, toleransi adalah bersifat atau bersikap menenggang atau menghargai, membiarkan, membolehkan. ${ }^{33}$ Bahasa latin, toleransi berasal dari dari kata, "tolerate" yang artinya membiarkan sesuatu. Sedangkan dalam Bahasa Arab, kata toleransi yaitu tasamuh yang artinya membolehkan sesuatu. Toleransi menjadi hak setiap manusia untuk diperlakukan

\footnotetext{
31Nurcholish Madjid, Masyarakat Religius..., hlm. 25.

32Nurcholish Madjid, Islam Kerakyatan dan Keindonesiaan (Bandung: Mizan, 1993), hlm. 17.

33Tim Penyusun Kamus Pusat Bahasa, Kamus Besar..., hlm. 1204.
} 


\section{Nurjannah Nasution}

setara tanpa memperhitungkan lagi latarbelakang agama, etnisitas ataupun sifatsifat spesifik yang dimiliki seseorang. ${ }^{34}$

Toleransi adalah manusia mempunyai kesanggupan menghormati sikap asal, keimanan dan perbuatan yang ada pada manusia yang lain. Dalam Islam toleransi berarti tasamuh, yaitu manusia yang memiliki sikap atau sifat menghargai, mendiamkan atau memperkenankan pendapat manusia lain kontradiktif dengan pendapatnya. Toleransi adalah memperkenankan yang kelihatan sampai kesemuanya terbuka. ${ }^{35}$

Beberapa hal telah dilakukan oleh Rasulullah saw terhadap para sahabatnya serta masyarakat Madinah dan sekitarnya yang terdiri dari berbagai ras, etnik, bahasa dan agama. Seorang Bilal, budak berkulit hitam yang tidak dikenal dari etnik negro Afrika, Abdurrahman bin 'Auf, dengan intelek Yahudi Abdullah bin Salam, dengan pembisnis berdarah Romawi Shuhaib ar-Rumi, dengan pemikir besar Salman al-Farisy dan lain-lain. Sikap dan karakter insklusif multikultural itu yang membawa Rasulullah saw dapat membangun kerjasama melalui Mistaq Madinah, dapat menampilkan sikap yang toleran terhadap Nasrani Najran, dapat menampilkan sikap elegan di hadapan orang-orang Quraisy Mekah setelah mereka memusuhi Beliau selama 20 tahun. ${ }^{36}$

Menurut Nurcholish Madjid, toleransi merupakan persoalan tentang ajaran serta kewajiban dalam melaksanakannya. Adapun hikmah dari pelaksanaannya yaitu menghasilkan sebuah interaksi yang baik antara berbagai kelompok yang berbeda ketika sikap toleransi diaplikasikan dalam keseharian. ${ }^{37}$

"Jaminan dasar akan keselamatan keyakinan agama masing-masing, bagi para warga masyarakat melandasi hubungan antar warga masyarakat atas dasar sikap saling hormat, yang akan mendorong tumbuhnya kerangka sikap tenggang rasa dan saling pengertian yang besar. Terlepas dari demikian kentalnya perjalanan sejarah dengan penindasan, kesempitan pandangan dan kezaliman terhadap kelompok minoritas yang berbeda

${ }^{34}$ Yaya Suryana dan A. Rosdiana, Pendidikan Multikultural..., hlm. 158.

${ }^{35 N g a i n u n}$ Naim, Pendidikan Multikultural..., hlm. 77.

${ }^{36}$ Muhammad Tholchah Hasan, Pendidikan Multikultural..., hlm. 72.

${ }^{37}$ Nurcholish Madjid, Islam Doktrin..., hlm. 190. 
keyakinan agamanya dari keyakinan mayoritas. Sejarah umat manusia membuktikan bahwa sebenarnya toleransi adalah bagian inherent dari kehidupan manusia". 38

Dalam sejarah kehidupan umat Islam, perbedaan keyakinan dalam beragama merupakan sebuah fitrah dan sikap toleransi yang telah diletakkan Nabi Muhammad saw untuk membangun Madinah. Nabi Muhammad saw melihat adanya multikultural yang terdapat di kota Madinah setelah seperti keragaman etnis. Masyarakatnya tidak hanya beragama Islam saja akan tetapi ada yang beragama Yahudi dan Nasrani. Dengan realita tersebut, Nabi Muhammad saw berinisiatif untuk membangun kebersamaan dari keragaman agama sehingga lahir yang namanya Piagam Madinah. Piagam Madinah merupakan dokumen pertama yang di dalamnya meletakkan prinsip kebebasan beragama. ${ }^{39}$

Agar tidak terjadi konflik atau perpecahan dalam menjalankan ajaran agama maka solusinya harus bersikap toleransi. Dalam kehidupan beragama, sikap toleransi harus dibiasakan dan menjadi suatu kesadaran pribadi dalam berinteraksi sosial.

\section{PENUTUP}

Makna multikultural dalam perspektif Nurcholish Madjid bahwa beliau lebih banyak menyebut istilah multikultural dengan istilah pluralitas. Nurcholish Madjid memahami pluralitas sebagai suatu masyarakat majemuk atau plural yang merupakan sebuah design atau sunnatulah Allah swt untuk umat manusia. Dalam pemikirannya banyak tertuang percikan-percikan mengenai persoalan nilai-nilai pendidikan multikultural. Pada nilai demokrasi, Nurcholish Madjid menyatakan harus absolutivisme, yaitu mengutarakan pendapat dan menerima kritikan. Selanjutnya, harus bersikap adil terhadap semua komponen dalam berkehidupan, yaitu harus menjadi wasit (penengah). Terhadap keragaman yang ada harus adanya nilai persamaan, yaitu ukhuwah antar satu sama lain harus dijalin dengan harmonis dan tentram. Dengan hal itu, maka keragaman yang ada dapat dirangkul dengan penuh penghargaan. Manusia yang satu dengan yang lain adalah sama,

38Nurcholish Madjid, Islam Universal(Yogyakarta: Pustaka Pelajar, 2007), hlm. 3.

39Nurcholish Madjida, Cita-Cita..., hlm. 195. 


\section{Nurjannah Nasution}

yaitu sama-sama mempunyai hak dan kewajiban maka tidak adanya perbedaan, yang membedakannya adalah tingkat ketaqwaan masing-masing. Kemudian, harus bersikap toleran terhadap semua agama, yaitu menghormati agama lain dan memberi kebebasan untuk beribadah serta tidak menghakimi seseorang dalam menyakini agama lain.

Oleh sebab itu, pendidikan multikultural sangat penting untuk disosialisasikan baik lewat seminar, workshop maupun pengadaan buku-buku tentang pendidikan multikultural. Masyarakat Indonesia adalah masyarakat yang majemuk dan perlu sekali untuk direalisasikan sikap demokrasi, keadilan, kemanusiaan, kesetaraan dan toleransi pada setiap individu agar tidak terjadi konflik yang mengakibatkan kerusuhan. Untuk itu, bagi peneliti lain diharapkan agar dapat meneliti tentang nilai-nilai pendidikan multikultural dari perspektif pemikiran tokoh Muslim yang lain ataupun dari pemikiran Nurcholish Madjid sendiri pada aspek yang berbeda.

\section{DAFTAR PUSTAKA}

Abdul Aziz, "Desain Pendidikan Multikultural dalam Pendidikan Islam', Jurnal Penelitian Realita, Volume 15 Nomor 1 Tahun 2017.

Abdullah Aly, Pendidikan Islam Multikultural di Pesantren, Yogyakarta: Pustaka Pelajar, 2011.

Haidar Putra Daulay, Pemberdayaan Pendidikan Islam di Indonesia, Jakarta: Rineka Cipta, 2009.

Haryanto Al-Fandi, Desain Pembelajaran yang Demokratis dan Humanis, Jogjakarta: Ar-Ruzz media, 2011.

Kementerian Agama Islam RI, Al-qur’an Al-Karim dan Terjemahannya, Semarang: Halim, 2014.

Muammar Munir, "Nurcholish Madjid dan Harun Nasution serta Pengaruh Pemikiran Filsafatnya", Jurnal Petita, Volume 2 Nomor 2 Tahun 2017.

Muhammad Tholchah Hasan, Pendidikan Multikultural Sebagai Opsi Penanggulang Radikalisme, Malang: Universitas Malang, 2011. 
Nana Syaodih, Metode Penelitian Pendidikan, Bandung: Remaja Rosdakarya, 2009.

Nurcholish Madjid, Cita-Cita Politik Islam Era Reformasi, Jakarta: Paramadina, 1999.

Nurcholish Madjid, Islam Agama Kemanusiaan, Jakarta: Paramadina, 1995.

Nurcholish Madjid, Islam Doktrin Islam Doktrin dan Peradaban, Jakarta: Paramadina, 2005.

Nurcholish Madjid, Islam Kemodernan dan Keindonesiaan, Bandung: Mizan, 2008.

Nurcholish Madjid, Islam Kerakyatan dan Keindonesiaan, Bandung: Mizan, 1993.

Nurcholish Madjid, Islam Universal, Yogyakarta: Pustaka Pelajar, 2007.

Nurcholish Madjid, Masyarakat Religius, Jakarta: Paramadina, 1997.

Samrin, "Konsep Pendidikan Multikultural", Jurnal al-Ta'dib, Volume 7 Nomor 2 Tahun 2014.

Syahrin Harahap, Metodologi Studi Tokoh Pemikiran Islam, Jakarta: Prenada, 2011.

Syahrin Harahap dan Hasan Bakti Nasution, Ensiklopedi Akidah Islam, Jakarta: Kencana, 2009.

Tim Penyusun Kamus Pusat Bahasa, Kamus Besar Bahasa Indonesia, Jakarta: Balai Pustaka, 2011.

Usman, "Civil Society dan Multikulturalisme dalam Pendidikan Islam", Jurnal Tadrîs, Volume 11 Nomor 1 Tahun 2016.

Yaya Suryana dan A. Rusdiana, Pendidikan Multikultural Suatu Upaya Penguatan Jati Diri Bangsa, Bandung: Pustaka Setia, 2015.

Zakiyuddin Baidhawy, Pendidikan Agama Berwawasan Multikultural, Jakarta: PT Erlangga, 2005. 